\title{
Neo-industrialization of Kuzbass economy in innovative development of coal industry and machinery
}

\author{
Anna Balabanova ${ }^{1}$, Vladimir Balabanov ${ }^{2}$, Elena Dotsenko ${ }^{3,}$ and Natalya Ezdina $^{3}$ \\ ${ }^{1}$ Russian Academy of Entrepreneurship, Rector, 109544, Moscow, 15, Malaya Andronievskaya st., \\ Russia \\ ${ }^{2}$ Russian Academy of Entrepreneurship, President, 109544, Moscow, 15, Malaya Andronievskaya st., \\ Russia \\ ${ }^{3}$ Plekhanov Russian University of Economics, Department of Political Economy and History of \\ Economic Science, 117997, Moscow, 36 Stremyanny lane, Russia
}

\begin{abstract}
As part of rental-resource model and access restrictions to capital and new technologies, the attempts to encourage import substitution made by the government do not generate innovative type of economic development and reconstruction of economy's manufacturing industry competitive on the domestic market. In conditions of searching for a new model of Russian economy development the analysis of a number of problems such as industry degradation, reducing the competitiveness of Russian producers, the growth of structural imbalances and overcoming the negative macroeconomic trends becomes strategically important. This raises the value of neo-industrialization as the integrator of resource security, scientific and industrial potential of Russian economy and high capacity of the domestic market in the innovative development system. A special role neo-industrialization plays for the economic development of old industrial regions, which include Kuzbass (Western Siberia, Russia). Neo-industrial development of Kuzbass economy should be initiated by the technological modernization of mining machinery and innovative development of coal industry.
\end{abstract}

\section{Introduction}

Modern structure of Russian economy, being developed within the framework of market model, does not generate an innovative type of development. In conditions of high entropy of market processes it becomes evident that without neo-industrial transformation, the recovery of manufacturing industry on a new convergence-technological base, raising the share of high-tech industries the instability of macroeconomic system is increasing, the risks for economic and geopolitical security are growing up [1]. Also the growth of technological gap between Russia and developed countries leads to the accumulation of environmental problems in resource extracting regions like Kuzbass (Western Siberia, Russia) [2, 3].

\footnotetext{
* Corresponding author: ktyf110372@,rambler.ru
} 
Establishing innovative paradigm of old industrial regions increases the requirements to the institutional structure of economy, raises the priority of cooperation between the state institutions, science and business, investment innovations. The leading role is played by the analysis of clustering process of innovative activity and structuring the competitive advantages of Russian economy, which are not connected with mineral resource export.

An integral economic component of neo-industrial development of mining areas is the integration of technological ideas and investments in industrial production, the expansion of national manufacturing complex in the world market with the following change of the export structure. Lagging of processing import-substitution threatens the loss of Russian technological identity, strengthening raw vector of long-term social-and-economic development. In this regard, the relevance of neo-industrial transformations of Russian economy in the process of changing its structure is increasing.

\section{Material and method}

Today it is important to restore the dominance of industrial complex in Russian economy, which will decrease the share of pre-industrial economy and will contribute to the formation of post-industrial layer. This, characteristic for the latter, estrangement from the material production should be the consequence of the high level of technological development of industry. Therefore, neo-industrial structural transformation of Russian economy is put on with the strategic task of improving profitability, investment attractiveness and international competitiveness of industrial production.

Neo-industrialization of economy is a systemic state policy of structural reforms in three main areas [4-6].

Firstly, the creation of institutional, financial, social, technological, market conditions for innovative development of the basic branches of Russian economy - coal, oil and gas, chemical, metallurgical industries, machinery, as well as restoring the production of the $5^{\text {th }}$ technological layer (electronics, aircraft and ship building) on a new technological basis.

Secondly, the profound transformation of technological and sectoral economic structure - the development of the industries of the $6^{\text {th }}$ technological layer based on convergent technologies. Their resource base and, at the same time, consumers of "breakthrough innovation" should become modernized basic and manufacturing industries.

Third, the profound changes of reproduction, institutional, market-competitive, social structure, which, on the one hand, should create the necessary conditions for neoindustrialization, on the other hand, become its result.

\section{Results and discussion}

The purpose of neo-industrialization is to overcome the de-industrialization of Russian economy (reduction of technological level of industry and its share in GDP, loss of its infrastructure, fixed assets and intellectual basis) and to come out at the same technological trajectory with the leading countries.

One of the key questions that have to be answered is the role of fuel and energy complex in the economy. In particular, whether the fuel and energy complex to be its donor or driver? Here we should have a look at the model of other countries. In the USA, the fuel sector plays a minor role in terms of fiscal revenue, exports and GDP, but in the total investments the sector accounts for about $15 \%$, i.e. it significantly affects the development of related industries. In Saudi Arabia, by contrast, the share of oil industry in GDP exceeds $50 \%$, while revenues from the fuel and energy complex are $90 \%$. In fact, the rest of 
economy merely serves the oil industry. Now let us look at Russia and Norway, the indicators of which are sufficiently close: in Russia the share of the fuel and energy complex in GDP is $21 \%$ (in Norway - 24\%), in investments - 24\% (in Norway - 29\%), in the consolidated budget - over $30 \%$ [7]. In both cases the oil and gas industry is important both for the economy as a whole and for the budget [8].

Which model of industrial development should Russia aim - Saudi Arabian, Norwegian or North American, or maybe just not to change anything? To do this it is important to understand the differences between two fundamentally different models of fuel and energy complexes. The sector plays the role of donor, when it has a high level of tax burden, when the budget is highly dependent on oil and gas revenues, as well as, in some cases, when consumers are subsidized with low energy prices [9]. Fuel and energy complex becomes a driver when energy production and consumption are based on new technologies.

In this system Russian (and China) takes an intermediate position between Saudi Arabia and North America. In the North American model (the USA and Canada) the high level of GDP per capita is not due to the oil and gas sector, but due to the economy diversification. In Saudi Arabia, on the other hand, fairly high standard of living is achieved mainly due to the production of hydrocarbons [10-11]. The similar situation is in Norway, where oil and gas sector is, however, the donor and the driver of economy. But Russia, even with the full involvement of resources, cannot reach the level of the Norwegian production of carbohydrate per capita: 142 million people live in Russia compared with 5 million in Norway. Thus, if the goal is to increase the level of life, fuel and energy complex should help neo-industrialization of economy.

To what extent Russian fuel and energy complex is the donor, and to what extent is the driver of neo-industrial development? Of approximately 20 trillion rubles of its annual revenues about 8 trillion is spent on taxes and fees and, according to our estimates, of about 4 trillion rubles on subsidizing the domestic market due to regulated low gas prices and customs duties on petroleum products (causing domestic prices to be lower than the world). Thus, the oil and gas sector donation can be relatively estimated at $60 \%$ of its revenue [12].

The remaining $40 \%$ is the potential to transform the sector into economic driver. The part of its expenditures including operating costs and capital investments have already been playing this role: they are directly converted into the income of related industries and population, stimulating their growth and consumer demand. However, incompletely capital investment can be carried out abroad; the services can be provided by foreign companies. According to our estimates, the localization level in Russian fuel and energy complex is about $80 \%$ (the share of equipment and services of foreign companies is about $20 \%$ ) [13]. This can be considered as evaluation of driver's effect from the fuel and energy complex activity [14]. Regarding to Kuzbass economy (Kemerovo region), in which coal industry dominates, neo-industrialization driver is an innovative development of machinebuilding. A special role is played by its segment producing equipment for the mining companies [15]. In this regard, we propose the development of Kuzbass neo-industrial cluster directed for the solution of the following tasks:

1. Radical reconstruction, technical and technological modernization of the regional machine-building, much of which was created in 1960-70-ies and has an average level of fixed capital depreciation about $70 \%$. At the same time for the whole period of market reforms the mass replacement of the production means in Kuzbass machine-building haven't occurred that enhances the technological gap between regional producers and foreign competitors, and complicates the start of import substitution.

2. Breaking the vicious circle of investment and production problems: significant physical deterioration of fixed capital - reducing the international competitiveness of machinery production - decreasing of sales - the lack of investment resources for the 
modernization of production - further increase of physical depreciation. This requires the formation of a single investment regional machinery program that reflects the needs for the new equipment of coal, chemical, metallurgy industries in the region, credit and investment opportunities of banks and investment companies, as well as technological possibilities of machinery enterprises.

3. The increase of cooperation of the regional machinery enterprises, which is now estimated less than $10 \%$, and overcoming their technological disconnection. This is particularly important for the production of equipment and production systems with preliminarily defined options and addressed products competitive in the regional market. An important precondition for the development of cooperative relationships within cluster is the presence of non-profit organization "Association of Kuzbass Machinery Engineers" in the region which unites about thirty machinery enterprises of Kemerovo, Novosibirsk and Tomsk regions. The formation of neo-industrial machine-building cluster in Kuzbass should include the following actions of the interested parties - coal and machine-building enterprises; the regional authorities; research, design and educational organizations.

Firstly, the analysis of technological conditions of modernization of the machinebuilding enterprises necessary for the replacement of importing coal industry equipment taking into account the inter-firm cooperation. Also it is necessary to analyze investment needs and financial capabilities of banks and investment companies represented in the region. The results of this analysis should be the basis of the Development strategy of Kuzbass neo-industrial import substitution cluster of machine-building.

Secondly, making the list of cluster's residents which should include machine-building companies as well as entities of financial, research and educational spheres of the region. In addition, it is necessary to sign partnership agreements with foreign developers of modern machine-building technologies, computer software for providing intellectual property rights, patents and licenses.

Third, the formation of complex supply of modern machine-building products for the coal industry needs, as well as other industries of Kuzbass economy, capable in the middle term to replace the foreign equipment. This, in turn, should become the logical outcome of the regional machine-building complex modernization, and it involves the implementation of the following actions:

- the organization of the investment consortium, which should include the main consumers of machine-building products - enterprises of coal, chemical and machinebuilding industries, forming on a parity the investment pool in regional machine-building;

- the development of research-and-production and engineering firms' network with the participation of the leading international manufacturers of machinery;

- the establishment of the regional Agency to attract and protect the investments in import substitution of industrial products, the main focus of which should be placed on the machine-building industry, initiating neo-industrialization;

- the establishment of the guarantee fund of investments in machine-building, the main role in which should be played by the regional authorities.

- making the list of regional tax exemptions provided for the residents of import substitution machine-building cluster.

Currently, there is an urgent need for the development of complex regional target Program of neo-industrial import substitution in Kuzbass industry. The program should link the intensification of $\mathrm{R} \& \mathrm{D}$, investments in modernization of coal, the chemical and machine-building industries, professional equipment, the state support and guarantee of loans for enterprises. The main objective of this program should be improvement of the target for import substitution technological level of these industries up to the level of imported by Kuzbass enterprises equipment. 


\section{Conclusions}

Neo-industrialization of economy in mining region requires the development of relations between science, production and financial sector. To promote their development it is necessary to provide vertical integration of firms and research organizations, industrial enterprises, banks and financial companies into neo-industrial holdings. They should integrate the entire production chains of goods from mineral resource extraction, the output of materials and components up to promotion of finished products in the domestic market. Neo-industrial holdings can be based on production companies, as well as to be established by the transformation of the public-private partnerships into the business groups uniting industrial enterprises around commercial bank, concentrating in its hands the cash flows of enterprises and providing them with long-term loans, funding of leasing and bonds.

Along with the changes in the sectoral structure, neo-industrialization implies the formation of innovative-industrial clusters of network type, combining enterprises into a single research and production complex. In the innovative cluster the transfer of innovation into production must be implemented by centers of inter-cluster interaction and technological cooperation, as well as cross-platform contract centers. At the regional level there is an evident need for the formation of neo-industrial mining machinery cluster in Kuzbass. For its formation it is necessary to create an institutional structure of machinebuilding import substitution, including the investment consortium of machinery products consumers, an international network of industry innovation, research-and-production and engineering firms, regional Agency to attract and protect investments in import substitution of industrial products, guarantee investment fund in machine-building, complex regional tax exemption for the residents of import substitution cluster.

\section{References}

1. M. Gasanov, S. Zhironkin, Procedia - Social and Behavioral Sciences, 166, 97 (2015)

2. Yu.V. Lesin, S.Yu. Luk'yanova, M.A. Tyulenev, J. Min. Sci., 46:1, 78 (2010)

3. M.A. Tyulenev, Y.V. Lesin, Mining 2014: Taishan academic forum - Project on mine disaster prevention and control, 441 (Atlantis Press, 2014)

4. S. Zhironkin, V. Guzyr, EpSBS, VII, 160 (2016)

5. M. Gasanov, S. Zhironkin, M. Hellmer, EpSBS, XIX, 745 (2017)

6. S. Zhironkin, M. Gasanov, O. Zhironkina, EpSBS, VII, 124 (2016)

7. M. Gasanov, S. Zhironkin, EpSBS, VII, 117 (2016)

8. S. Zhironkin, M. Gasanov, O. Zhironkina, EpSBS, XIX, 753 (2017)

9. F. Janszen, The age of Innovation (London, Prentice Hall, 2000)

10. S. Zhironkin, M. Gasanov, O. Zhironkina, E. Taran, SHS Web of Conferences, 28, 01145 (2016)

11. S. Zhironkin, M. Gasanov, K. Kolotov, EpSBS, XIX, 761 (2017)

12. A. Zhavoronok, M. Gasanov, S. Zhironkin, SHS Web of Conferences, 28, 01144 (2016)

13. A.S. Yakovlev, Natural resource bulletin, 2 (2014)

14. E.S. Demidenko, E.A. Dergacheva, Technogenic development of society and biosphere transformation (Moscow, Krasand, 2010)

15. M.Y. Blashchuk, A.A. Kazantsev, R.V. Chernukhin, App. Mech. Mat, 682, 418 (2014) 